function. This has been shown with nephrotoxic agents in rats and dogs (Ellis et al., 1973). Increases in urinary NAG activity were detected in this series up to three weeks before acute rejection was recognized by established methods.

Although the concentration of NAG in the kidney is particularly high it is also found in the extrarenal tissues of the human urogenital tract and in semen. This should be borne in mind when interpreting results. Thus during an uncomplicated postoperative period, although a smooth fall in urinary NAG may be expected, a rise in enzymes may indicate renal cell damage (rejection, acute tubular necrosis, or renal vascular complications) or damage to some other portion of the urogenital tract, such as the ureter. A preliminary study of some human urinary pathogens suggests that bacteria themselves do not release NAG, GAL, or AP into the urine.

\section{Conclusion}

Estimation of the activity of NAG in the urine of patients with transplanted kidneys is of value in the early detection of renal cell damage in acute rejection of the graft. It is also a useful confirmatory test for chronic rejection. Nevertheless, other causes of renal cell damage may be expected to cause raised urinary NAG levels and should be excluded. LDH, GAL, and AP may be of limited value, but GLU does not appear in the urine in sufficient quantities to be of use. Changes in the serum levels of these enzymes do not always correlate with changes in the urinary enzymes, and rises in serum activity do not correlate closely with episodes of acute rejection of the transplanted kidney.

We should like to thank Mr. M. Bewrick, of Guy's Hospital, London, and Dr. B. Hulme, of St. Mary's Hospital, London, members of the Southern Transplant Group, for permission to study patients under their care and for their help and encouragement. We should also like to thank Dr. L. Ellis, of the biochemistry department of St. Thomas's Hospital, Lambeth, for help with urinary LDH assays, and Mrs. E. Brown, who did many of the LDH assays. The help of Dr. I. Phillips, department of bacteriology, St. Thomas's Hospital, and Miss N. Salmon, depantmint of social medicine, St. Thomas's Hospital, is gratefully acknowledged. This work has been generously supported by the Endowment Funds of St. Thomas's Hospital and by a grant from the National Kidney Research Fund.

\section{References}

Amador, E., Dorfman, L. E., and Wacker, W. E. G. (1963). Clinical Chemistrv, 9, 391.

Ballantyne, R., Wood, W. G., and Meffan, P. M. (1968). British Medical fournal, 2, 667.

Braun, W. E., and Merrill, J. P. (1968). New England fournal of Medicine, 278, 1366 .

Carter, B. A. (1970). Publication from Department of Biochemical Sciences, University of Surrey.

Dance, N., Price, R. G., Cattell, W. R., Landsell, J., and Richards, B. (1970). Clinica Chimica Acta, 27, 87.

Dorfman, L. E., Amador, E., and Wacker, W. E. G. (1963). fournal of the American Medical Association, 184, 1.

Ellis, B. G., Price, R. J., and Topham, J. C. (1973). Unpublished data.

Fernley, H. N., and Walker, P. G. (1965). Biochemical fournal, 97, 95.

Hamburger, T. J. (1972). Proceedings of the Royal Society of Medicine, 65, 1051 .

Leaback, D. H., and Walker, P. G. (1961), Biochemical fournal, 78, 151.

Noble, R. E., Najarian, J. S., and Brainerd, H. D. (1965). Proceedings of the Society for Experimental Biology and Medicine, 120, 737.

Price, R. G., Dance, N., Richards, B., and Cattell, W. R. (1970). Clinica Chimica Acta, 27, 65

Prout, G. R., Macalalag, E. V., and Hume, D. M. (1964). Surgery, 56, 283.

Ringoir, S., Wieme, R. J., and Derom, F. (1968). Excerpta Medica International Congress Series, No. 179, p. 270.

Robinson, D. (1970). In 7th International Congress of Clinical Chemistry, Vol. 1, p. 42. Basel, Karger.

Robinson, D., Price, R. G., and Dance, N. (1967). Biochemical fournal, 102,

Shah, B. C., Ambrus, J. L., Mink, I. B., Albert, D. J., Sampson, D., and Murphy, G. P. (1972). Transplantation, 14, 705.

\title{
Postinfective Malabsorption: A Sprue Syndrome
}

\author{
R. D. MONTGOMERY, D. J. BEALE, H. G. SAMMONS, R. SCHNEIDER
}

British Medical fournal, 1973, 2, 265-268

\begin{abstract}
Summary
Thirteen cases are described of temporary malabsorption in adults presenting after an episode of apparent infective enteritis. Clinical features included diarrohea, anorexia, and weight loss. Investigations indicated diffuse impairment of function in the small bowel, including the ileum, with well-preserved mucosal morphology in the upper jejunum and a tendency to rapid folate depletion. Spontaneous recovery usually occurred within weeks but two cases ran a more prolonged and severe course.

The clinical features of this syndrome are those of tropical sprue, but the outcome of the illness is probably influenced by nutritional as well as environmental factors. There may be a gradation of severity of illness from megaloblastic anaemia to florid malabsorption syndrome.
\end{abstract}

Metabolic Unit, East Birmingham Hospital, Birmingham B9 5ST R. D. MONTGOMERY, M.D., F.R.C.P., Consultant Physician

D. J. BEALE, M.B., Medical Registrar

D. J. BEALE, M.B., Medical Registrar

R. GCHNEIDER, M.D., F.R.C.P., Consultant Physician

\section{Introduction}

Intestinal malabsorption may persist for short periods after specific bacterial dysenteries (King and Joske, 1960; Sprinz et al., 1962), cholera (Lindenbaum, 1965), and viral infection (Sabin, 1956; Blacklow et al., 1972). Many of these reported cases were asymptomatic. The significance of this phenomenon has been debated, particularly in relation to the evolution of tropical sprue.

Apart from one case report (Drummond and Montgomery, 1970) temporary malabsorption of this kind has not previously been described in this country. We report findings in 13 symptomatic cases of malabsorption presenting in Britain after an acute episode of apparent infective enteritis. The condition usually ran a benign course, but two patients had a more prolonged and severe illness.

\section{CLINICAL FEATURES}

The salient features of the syndrome were: (1) acute onset of diarrhoea, sometimes with initial vomiting and fever and sometimes accompanied by similar symptoms in close contacts; (2) prolongation of less severe diarrhoea with abdominal 
discomfort and distension, anorexia, malaise, and a tendency to mental depression; and (3) lasting recovery within a few months.

The patients were aged 20 to 59 years, seven of them being in their twenties. None of them had lived in the tropics and none had any previous history of abdominal disorder either in adult life or childhood. Five were on holiday when the initial attack began - two in Britain, one in Spain, one camping in Switzerland, and one motoring through Turkey. In three of these cases other members of the party or family were similarly affected at the same time but recovered in a day or two. Several of the patients had had courses of antibiotics for their symptoms, but only for a few days. None had had blood in the stools.

They had all had contimsous symptoms for 6-12 weeks at the time of admission, they were all anorexic, and they had lost between 3 and $13 \mathrm{~kg}$ in weight, with a mean loss of $8.3 \mathrm{~kg}$. Mental depression or irritability was a noticeable feature in four cases. Clinical examination showed nothing abnormal except that the abdomen tended to be bulky. There were no mucocutaneous abnormalities, except in one patient who developed glossitis, aphthous stomatitis, and blepharitis.

\section{INVESTIGATIONS}

Haematology.-Serum vitamin $B_{12}$ levels ranged from 170 to $1,000 \mathrm{pg} / \mathrm{ml}$. The serum iron was reduced in only two cases. In six patients the serum folate was less than $2.5 \mathrm{ng} / \mathrm{ml}$, and in another, first seen in 1961, urinary formiminoglutamic acid (FIGLU) excretion was markedly increased and folinic acid excretion was diminished. Data on cases with anaemia or re-

TABLE I-Haematological Findings in Nine Cases with Anaemia or Lorv Serum Folate Levels

\begin{tabular}{|c|c|c|c|c|c|}
\hline Case No. & $\underset{(\mathrm{g} / 100 \mathrm{ml})}{\mathrm{Hb}}$ & Blood Film & $\begin{array}{c}\text { Serum } \\
\text { Folate } \\
\text { (ng/ml) }\end{array}$ & $\begin{array}{c}\text { Serum } \\
\mathbf{B}_{1:} \\
(\mathbf{p g} / \mathrm{ml})\end{array}$ & $\begin{array}{c}\text { Serum } \\
\mathbf{F e} \\
(\mu \mathrm{g} / 100 \mathrm{ml})\end{array}$ \\
\hline 1 & 10.8 & Macrocytic & (FIGLU & - & - \\
\hline $\begin{array}{r}2 \\
3 \\
4 \\
6 \\
7 \\
8 \\
10 \\
11\end{array}$ & $\begin{array}{r}13.3 \\
10.0 \\
13.6 \\
9.0 \\
14.0 \\
14.6 \\
12.0 \\
12.6\end{array}$ & $\begin{array}{l}\text { Normal } \\
\text { Dimorphic } \\
\text { Normal } \\
\text { Macrocvtic } \\
\text { Normal } \\
\text { Normal } \\
\text { Normal } \\
\text { Mild hypochromia }\end{array}$ & $\begin{array}{l}2.1 \\
0.8 \\
2.0 \\
0.3 \\
2.8 \\
2.0 \\
2.1 \\
4.3\end{array}$ & $\begin{array}{l}\overline{649} \\
170 \\
291 \\
385 \\
480 \\
945\end{array}$ & $\begin{array}{r}\overline{56} \\
90 \\
70 \\
60 \\
142 \\
43\end{array}$ \\
\hline
\end{tabular}

TABLE II-Results of Schilling Test with and without Intrinsic Factor (I.F.)

\begin{tabular}{|c|c|c|c|}
\hline \multirow{2}{*}{ Case No. } & \multirow{2}{*}{$\underset{(\mathbf{p g} / \mathbf{m l})}{\operatorname{Serum}} \mathbf{B}_{1 \mathbf{2}}$} & \multicolumn{2}{|c|}{ Recovery of Urinary Cobalt (\%) } \\
\hline & & Without I.F. & With I.F. \\
\hline $\begin{array}{r}7 \\
8 \\
9 \\
10 \\
11 \\
12\end{array}$ & $\begin{array}{l}291 \\
385 \\
170 \\
480 \\
945 \\
203\end{array}$ & $\begin{array}{r}16.3 \\
2.8 \\
6.0 \\
7.7 \\
10 \cdot 2 \\
2.4\end{array}$ & $\begin{array}{r}20.0 \\
6.2 \\
6.2 \\
7 \cdot 6 \\
3.2\end{array}$ \\
\hline
\end{tabular}

duced serum folate are given in table I. The serum folate level bore no relation to the duration of the illness, but the patients with macrocytic anaemia had the most severe clinical features of the group.

Intestinal Function.-The xylose test showed nothing abnormal in four patients (who all had steatorrhoea); in the other nine cases urinary xylose excretion was reduced (see fig.). The reduction tended to be as great in the two to five hour period as in the first two hours, a pattern characteristic of disorder of the lower half of the small bowel (Sammons et al., 1967). A Schilling test was performed in six cases and results were abnormal in five of them (table II). Long-chain faecal fat excretion was variable at the time of first investigation. In three patients steatorrhoea greater than $30 \mathrm{~g} /$ day decreased to less than $12 \mathrm{~g} /$ day within three weeks. In six other cases the initial levels were 6-12 g/day, and in four they were normalbut two of these had a minimal fat intake due to severe anorexia. There was no correlation between the xylose absorption figures and the level of fat excretion (table III). Faecal nitrogen excretion was increased in all nine patients in whom it was studied (table III). In three of these it rose to over $3 \mathrm{~g} /$ day during early recovery, with increased intake. The excretion of volatile fatty acids was usually within the normal range, but lactic acid excretion was increased in four out of seven patients to $280-1,200 \mathrm{mg} /$ day.

Other Biochemical Tests. - The total serum calcium was reduced in three patients $(7 \cdot 8-8.8 \mathrm{mg} / 100 \mathrm{ml})$ in whom the serum albumin was within normal limits. The serum orosomucoid was raised in two cases (154 and 160 units) and ranged from 32 to 112 units in six others. Pancreatic enzymes in duodenal juice were estimated in eight cases and showed normal activity. Two patients of average clinical severity had abnormal results of liver function tests without jaundice (raised serum alkaline phosphatase and 5-nucleotidase, and delayed bromsulphalein excretion).

Microbiology.-Widal agglutination tests and repeated stool cultures showed no pathogens. Results of tests for ova and cysts were negative, and no Giardia parasites were found in stools, jejunal aspirates, or biopsies. Aerobic culture of duodenojejunal juice showed scanty organisms in four specimens only (Streptococcus viridans, Escherichia coli, and Proteus species).

Radiology.-Barium follow-through examination performed at an early stage in 11 cases showed abnormalities in all of them. These fonsisted of flocculation or dilution by increased mucus secretion, mucosal oedema with thickened folds, and variable degrees of dilatation. The changes were diffuse, but in four cases they appeared to be maximal in the lower jejunum and in one of these the dilatation was severe. In three cases dilatation was most pronounced in the ileum. There was no obvious abnormality of transit time except for two cases in which there was noticeable hurry. The severity of radiological changes did not correlate with the clinical state or with the degree of steatorrhoea. In the remaining two patients a barium study was delayed until they were symptom-free, and in both cases the $x$-ray appearance was normal.

TABLE III-Clinical and Investigative Data of all Cases on First Admission

\begin{tabular}{|c|c|c|c|c|c|c|c|c|c|c|c|}
\hline $\begin{array}{l}\text { Case } \\
\text { No. }\end{array}$ & $\begin{array}{c}\text { Age } \\
\text { in years }\end{array}$ & Sex & $\begin{array}{c}\text { Length } \\
\text { of History } \\
\text { (Weeks) }\end{array}$ & $\begin{array}{c}\text { Approximate } \\
\text { Weight } \\
\text { Loss } \\
\text { (kg) } \\
\end{array}$ & $\underset{(\mathrm{g} / 100 \mathrm{ml})}{\mathrm{Hb}}$ & $\begin{array}{c}\text { E.S.R. } \\
\text { WWestergren } \\
\text { (mm in } 1 \mathrm{hr})\end{array}$ & $\begin{array}{c}X \text {-rav } \\
\text { Abnormality }\end{array}$ & $\begin{array}{c}\text { Faecal } \\
\text { Fat } \\
\text { (Mean } \mathbf{g} / \text { day) }\end{array}$ & $\begin{array}{c}\text { Faecal } \\
\text { Nitrogen } \\
\text { (Mean g/day) }\end{array}$ & $\begin{array}{l}\text { Xylose Test } \\
(5 \mathrm{hr} \\
\text { Excretion \%) }\end{array}$ & $\begin{array}{l}\text { Time From } \\
\text { Admission } \\
\text { to Clinical } \\
\text { Recover } \\
\text { (Weeks) }\end{array}$ \\
\hline $\begin{array}{c}1 \\
2 \\
3 \\
4 \\
5 \\
6 \\
7 \\
8 \\
9 \\
10 \\
11 \\
12 \\
13\end{array}$ & $\begin{array}{l}47 \\
41 \\
29 \\
24 \\
24 \\
34 \\
22 \\
24 \\
23 \\
58 \\
51 \\
59 \\
20\end{array}$ & $\begin{array}{l}\mathrm{F} . \\
\mathrm{F} . \\
\mathrm{F} \\
\mathrm{F} \\
\mathrm{F} \\
\mathrm{M} . \\
\mathrm{F} . \\
\mathrm{F} \\
\mathrm{F} \\
\mathrm{M} . \\
\mathrm{F} . \\
\mathrm{F} \\
\mathrm{F} \\
\mathrm{M}\end{array}$ & $\begin{array}{r}8 \\
9 \\
6 \\
7 \\
6 \\
6 \\
7 \\
8 \\
8 \\
7 \\
7 \\
10 \\
12\end{array}$ & $\begin{array}{r}11 \\
3 \\
9 \\
6 \\
5 \\
6 \\
12 \\
14 \\
7 \\
8 \\
6 \\
12 \\
8\end{array}$ & $\begin{array}{l}10.8 \\
13.3 \\
10.0 \\
13.6 \\
14.4 \\
9.0 \\
14.0 \\
14.6 \\
14.6 \\
12.2 \\
12.6 \\
14.9 \\
13.2\end{array}$ & $\begin{array}{r}47 \\
6 \\
6 \\
13 \\
12 \\
57 \\
6 \\
7 \\
7 \\
7 \\
7 \\
10 \\
16 \\
11\end{array}$ & $\begin{array}{c}+ \\
+ \text { (late) } \\
- \text { (late) } \\
+ \\
+ \\
+ \\
++ \\
+ \\
+ \\
+ \\
+ \\
++ \\
++\end{array}$ & $\begin{array}{r}7.5 \\
5.0 \\
3.0 \\
5.5 \\
30.0 \\
10.0 \\
7.5 \\
1.0 \\
7.5 \\
41.0 \\
4.5 \\
6.0 \\
52.0\end{array}$ & $\begin{array}{l}2.5 \\
2.1 \\
2.2 \\
1.9 \\
2.7 \\
2.5 \\
2.6 \\
2.3 \\
2.9\end{array}$ & $\begin{array}{r}20 \\
4 \\
9 \\
3 \\
35 \\
9 \\
40 \\
11 \\
36 \\
19 \\
19 \\
20 \\
28\end{array}$ & $\begin{array}{r}26 \\
17 \\
3 \\
4 \\
3 \\
16 \\
2 \\
18 \\
2 \\
2 \\
4 \\
3 \\
4 \\
12\end{array}$ \\
\hline
\end{tabular}


fejunal Biopsy.-The appearance of upper jejunal biopsy specimens under the dissecting microscope ranged from normal in three cases to a preponderance of broad leaves and joining leaves in three cases. Intermediate appearances were of finger-shaped villi interspersed with variable numbers of leaves, with slight shortening. In no cases did the biopsy specimen show convolutions or a flat mucosa. Histology showed mild stunting and oedema of villi and increased depth of crypts in the more severely affected cases, but in most the villous appearance was well preserved. The morphology of the enterocytes and brush border appeared normal on light microscopy, and there was no excessive lymphocytic infiltration within the epithelium. The lamina propria appeared to have an abnormal lymphocytic and plasma cell infiltration in the three cases with broad leaves and mild atrophy. Disaccharidase estimations performed in seven biopsy specimens showed a marginal decrease in lactase, sucrase, and maltase activities in these three cases, and reduced lactase in one other (table IV).

TABLE IV-Disaccharidase Activity in fejunal Biopsy Specimens, showing Marginal Reduction in Four Cases. Figures in umol of Glucose/g wet weight/min. (Normal Values according to Sheehy and Anderson, 1965)

\begin{tabular}{c|c|c|c}
\hline Case No. & Lactase & Sucrase & Maltase \\
\hline Normal range: & $0.9-18 \cdot 1$ & $2 \cdot 8-58 \cdot 2$ & $5 \cdot 01-38 \cdot 1$ \\
& & & \\
\hline 7 & $8 \cdot 2$ & 12.0 & 33.0 \\
8 & 1.3 & 2.3 & $5 \cdot 2$ \\
9 & 0.5 & $6 \cdot 1$ & $19 \cdot 0$ \\
10 & 0.9 & 2.7 & $7 \cdot 2$ \\
11 & 0.9 & 19.6 & 72.9 \\
12 & 10.0 & 19.0 & 28.0 \\
13 & 12.0 & 20.0 & \\
\hline
\end{tabular}

\section{FOLLOW-UP}

In 11 patients the time from the onset of symptoms to clinical recovery ranged from nine to 26 weeks. During recovery in hospital, without treatment, stool fat excretion and xylose tests showed steady improvement to normal or near-normal levels (fig.). These patients were followed up for periods of from six months to four years. They all remained well. Occasional loose motions and colic in one case, and anorexia and depression in another, persisted for a few months only. Neither of these two showed any haematological abnormality.

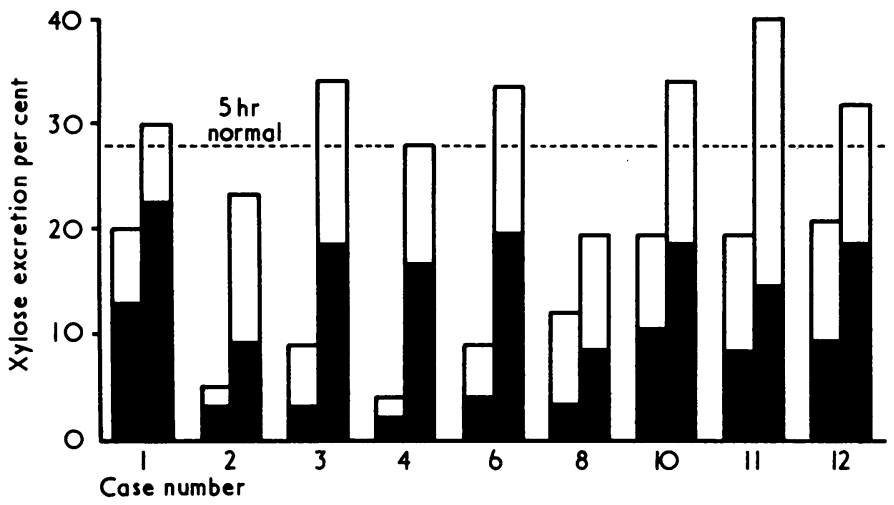

Results of 5-g xylose excretion tests in nine cases before and after clinical recovery. Shaded columns represent $0-2$ hour excretion and unshaded portions of columns represent 2-5 hour excretion.

Two patients (cases 1 and 6) ran a more prolonged and severe course. The initial clinical and laboratory findings were no different from those of the remainder, except that both had a macrocytic anaemia and a raised E.S.R. (table III) with mild pyrexia.

\section{Case 1}

This was a woman aged 47 whose illness began acutely in her own home in 1961. On admission after six weeks, in addition to the features mentioned, she had hypokalaemia and hyponatraemia; the serum albumin was $3.5 \mathrm{mg} / 100 \mathrm{ml}$ and calcium was $7.8 \mathrm{mg} / 100$ $\mathrm{ml}$. Jejunal biopsy showed minimal changes, with a minority of leafshaped villi. A barium follow-through showed diffuse changes of mucosal oedema and mild dilatation mainly in the lower jejunum and the ileum.

Diarrhoea and steatorrhoea persisted for three months. Parenteral folic acid corrected the anaemia but had no effect on the bowel symptoms or body weight. A 15-day course of antibiotics did not produce any improvement.

A trial was then made of a gluten-free diet and this coincided with an immediate clinical improvement, rapid weight gain, and improved xylose absorption. A repeat $\boldsymbol{x}$-ray examination five months after onset showed improvement, with mild changes confined to the ileum.

After six months on a gluten-free diet the patient had gained 14 $\mathrm{kg}$ and had no symptoms. The $\mathrm{Hb}$ was $13.5 \mathrm{~g} / 100 \mathrm{ml}$ and the fivehour xylose absorption was $35 \%$. Jejunal morphology was normal. A challenge of gluten, $15 \mathrm{~g} /$ day for 14 days, was then given. This produced no symptoms, no steatorrhoea, and no change in the pattern of xylose excretion.

The patient remained well on an unrestricted diet without treatment. Follow-up investigation after nine years showed a haemoglobin level of $15.1 \mathrm{~g} / 100 \mathrm{ml}$ and no evidence of malabsorption.

\section{Case 6}

The initial illness in this case has been described previously (Drummond and Montgomery, 1970). A 34-year-old woman with diarrhoea developed profound and progressive anaemia which was corrected only by parenteral folic acid therapy, which also produced a dramatic improvement in her symptoms and malabsorption. Eighteen months later she again developed acute "gastroenteritis" and had a prompt relapse of folic acid deficient anaemia which this time responded to oral folic acid. She subsequently remained symptom-free for two years without treatment, with normal haemoglobin and normal xylose absorption.

\section{Discussion}

Although no organisms were isolated, in all these patients there is little doubt that the illness was infective in origin. Five patients could be described as having had "travellers' diarrhoea." Pathogenic $E$. coli strains have been implicated in this condition (Keen and Waters, 1959; Rowe et al., 1970) and chemotherapy was found by Turner (1967) to be of prophylactic value. On the other hand, it seems that some such cases at least are due to a viral infection (Blacklow et al., 1972).

The condition we have described may be uncommon in Britain, but because of the poor correlation of the various parameters of malabsorption extensive investigations would be needed to show its extent. The main problem in differential diagnosis was to exclude gluten-induced enteropathy or mild regional ileitis-conditions in which acute symptoms may be precipitated by an intercurrent infection. The jejunal morphology did not suggest coeliac disease and follow-up in all cases has shown normal tolerance of gluten and no evidence of Crohn's disease. Some cases of infective enteritis are followed by symptoms of an "irritable bowel," but with no evidence of malabsorption. We have excluded these from our series, and none of our patients showed features of the irritable bowel syndrome either before or after their illness.

The low lactase and sucrase activity in several cases is similar to the defect described in tropical sprue (Sheehy and Anderson, 1965; Mathan and Baker, 1971) and after gastroenteritis in infants (Burke et al., 1965). According to Whitehead (1971) this is a sensitive index of reduced effective villous surface area. 
The question naturally arises as to whether these cases have the same pathogenesis as tropical sprue but tend to regress because of nutritional or local environmental factors (Logan, 1971). There is no clear answer to this question. Certainly the clinical, biochemical, radiological, and histological findings are indistinguishable from those of acute tropical sprue. Folate deficiency, and perhaps protein deficiency, play a key part in the evolution of tropical sprue and it may well be that the good nutritional state of the patients in our series affected the clinical course. The two severe prolonged cases were in social classes III and V, and the latter at least had been living on a rather poor and monotonous diet immediately before her illness. In contrast, the patients who contracted "traveller's diarrhoea" overseas, and who ran a benign course, were of social class I or II.

Tropical sprue in India tends to follow an epidemic pattern (Mathan and Baker, 1968). Invasion of the upper small bowel by colonic flora has been found in this condition and is thought to be an important initiating factor (Banwell and Gorbach, 1969). Similar colonization may accompany acute gastroenteritis in adults in "non-sprue" areas (Cohen et al., 1967).

Sprinz et al. (1962) and Lindenbaum (1965) observed abnormalities of xylose and vitamin $\mathbf{B}_{12}$ absorption persisting for periods of up to a year after bacterial dysenteries and cholera. None of these cases developed classical sprue, however, and these findings must be viewed against a high background level of symptomless malabsorption on the Indian subcontinent.

Just as the relation between clinical sprue and symptomless malabsorption in the tropics remains undefined, it seems that a parallel problem exists in Britain. The series we have described differs clinically from cases presenting as folatedeficient megoblastic anaemia with few or no intestinal symptoms and variable evidence of malabsorption. Such cases may relapse over a long period and tend to present in pregnancy (Giles, 1966; Whitfield, 1970). The series described by Cooke et al. (1963) as "temperate sprue" included a number in this category, but others had a recent history of acute diarrhoea. They resembled our cases with regard to jejunal morphology, and in the tendency to rapid folate depletion.
Possibly these various presentations reflect the same disorder. Postinfective malabsorption may progress insidiously or may occasionally pass into a relapsing state-as was suggested in case 6.

Stewart et al. (1967) described malabsorption without gluten sensitivity and with a convoluted mucosa in the relative of a gluten-sensitive patient. It has been suggested (Wellcome Trust, 1971) that cases of this sort differ from tropical sprue in that the proximal small bowel is involved rather than the distal. Significantly, no patients in the present series had relatives with coeliac disease; and the $x$-ray pictures, Schilling tests, and two to five hour xylose excretion all implied a considerable disorder of the ileum as well as the jejunum.

\section{References}

Banwell, J. G., and Gorbach, S. L. (1969). Gut, 10, 328

Blacklow, N. R. et al. (1972). Annals of Internal Medicine, 76, 993

Burke, V., Kerry, K. R., and Anderson, C. M. (1965). Australian Paediatric fournal, 1,147

Cohen, R., et al. (1967). Fournal of the American Medical Association, 201, 835 .

Cooke, W. T., Fone, D. J., Cox, E. V., Meynell, M. J., and Gaddie, R. (1963). Gut, 4, 292.

Drummond, M. B., and Montgomery, R. D. (1970). British Medical fournal,

2, 340. Miles, C. (1966). Fournal of Clinical Pathology, 19, 1.

Keen, B. H., and Waters, S. R. (1959). New England fournal of Medicine, 261, 71 .'

King, M. J., and Joske, R. A. (1960). British Medical fournal, 1, 1324

Lindenbaum, J. (1965). British Medical fournal, 2, 326.

Logan, J. S. (1971). Ulster Medical fournal, 40, 151.

Mathan, V. I., and Baker, S. J. (1968). American fournal of Clinical Nutrition, 21, 1077

Mathan, V. I., and Baker, S. J. (1971). In Tropical Sprue and Megaloblastic Anaemia. Wellcome Trust Collaborative Study 1961-69, p. 220. London, Churchill.

Rowe, B., Taylor, J., and Bettleheim, K. A. (1970). Lancet, 1, 1.

Sabin, A. N. (1956). Annals of the New York Academy of Sciences, 66, 228. Sammons, H. G., et al. (1967). Gut, 8, 348.

Sheehy, T. W. and Anderson, P. R. (1965). Lancet, 2, 1

Sprinz, $H$., et al. (1962). American fournal of Clinical Pathology, 38, 43.

Stewart, J. S., Pollock, D. J., Hoffbrand, A. V., Mollin, D. L., and Booth C. C. (1967). Quarterly fournal of Medicine, 36, 425 .

C. C. (1967). Quarterly fournal of Medicine, 36, 425.

Turner, A. C. (1967). British Medical fournal, 4, 653. Trust Collaborative Study 1961-69, p. 281. London, Churchill.

Whitehead, R. (1971). Journal of Clinical Pathology, 24, Suppl. No. 5, p. 108

Whitfield, C. R. (1970). Fournal of Obstetrics and Gynaecology of the British Commonwealth, 77, 577.

\title{
Prospective Study of Cytomegalovirus Infection in Pregnancy
}

\author{
H. STERN, S. M. TUCKER
}

British Medical fournal, 1973, 2, 268-270

\section{Summary}

In a prospective study of cytomegalovirus infection in 1,040 pregnant women in London $319(42 \%)$ of the white Englishwomen but only $28(10 \%)$ of the immigrant Asian women were without antibodies at the onset of pregnancy. Out of 254 susceptible white women and 16 susceptible Asian women $8(3 \%)$ and $3(16 \%)$ respectively

St. George's Hospital Medical School, London S.W.1

H. STERN, PH.D., F.R.C.PATH., Professor of Virology

Hillingdon Hospital, Middlesex

S. M. TUCKER, M.R.C.P., D.C.H., Consultant Paediatrician

experienced primary infection during the course of pregnancy. The overall incidence of fetal infection after primary infection in the mother was almost $\mathbf{5 0} \%$, and was higher in early pregnancy. One out of the five infected infants was found to be mentally retarded.

Reactivation of latent infection was recognized in $0.7-2.9 \%$ of pregnant women; this occurred without involving the fetus.

\section{Introduction}

Cytomegalovirus is one of the few agents known to damage the brain in utero. Infants who survive the classical syndrome of neonatal cytomegalic inclusion disease are usually mentally retarded and microcephalic (Weller and Hanshaw, 1962; Medearis, 1964). This severe illness, however, is comparatively 